\title{
Study of optimum conditions for vacuum frying carambolas
}

\author{
ChIH-YAO Hou ${ }^{* 1}$, Po-ChiH Wu ${ }^{* 1}$, I-Chen Yang*1 \\ HSIANG-Lin Huang ${ }^{* 1}$ and Ming-CHANG Wu*1 \\ * 1 Department of Food Science, National Pingtung University of Science and Technology \\ No.1, Hseuh Fu Road, Nei Pu, Pingtung, Taiwan 91201
}

The effects of various frying parameters on the quality of vacuum-fried carambolas were investigated. The three-variable three-level fractional factorial design response surface methodology was used to combine the operation conditions, and process variables including syrup-soaking time, frying temperature and frying time. The response variables were based on the overall acceptability determined through sensory evaluation; the highest overall acceptability was obtained by the combination of syrup-soaking at $30^{\circ}$ Brix for 1 hour, and then vacuum frying at $108^{\circ} \mathrm{C}$ for $46 \mathrm{~min}$. Model functions were verified as being adequate, using an optimum combination of syrup-soaking time, frying temperature and frying time. The result showed that vacuum-fried carambolas have good quality.

(Received Mar. 15, 2005 ; Accepted Aug. 22, 2005)

The carambola (Averrhou carambola. L) is also called star fruit, owning to its star shape. The fruit is juicy, has a strong flavor, and is very favorable in tropical areas, such as in the Southern Asia, Southern American, Hawaii, and Australia; in Taiwan, fresh carambolas can be supplied over 8 months. Thus, they are economically important in the region.

Snack foods are very popular among the young generation. Most traditional snack foods are made from cereals. Recently, vacuum-fried fruits have become popular hot snack foods. With for the diversity of carambola products, the vacuum frying of carambolas should be developed to obtain products that are crispy, and non oily, and have a good color retention. In this study, we surveyed the optimum conditions for vacuum frying carambolas.

The operation conditions were combined using the three-variable three-level fractional-factor designed response surface methodology (RSM). By RSM, the effect of response on multiple factors by simple experimental design, mathematic deduction and systematic analysis, the process variables including syrup-soaking time, frying temperature and frying time, and the response variables for overall acceptability of sensory evaluation can be determined. Frying temperature and frying time are the most significant factors in yielding study of vacuum frying. Syrup soaking can remove some water from the raw material, yielding a crispy product. Thus, syrup soaking time is also used as a variable factor in this study.

\section{Materials and Method}

\section{Materials}

- Carambolas were purchased from Mr. Lee's garden in Pingtung, Taiwan.

- Palm oil was purchased from Macro Wholesale Market.

- Sugar was from Taiwan Sugar Company.

- $\mathrm{CaCl}_{2}$ was from Nacalai Tesque, Inc. (Japan).

- Ethyl ether was from Tedia Company, Inc. (Germany).

\section{Equipment}

- The vacuum fryer used was purchased from Big John Factory (Mini-S 1 Type, Taipei, Taiwan).

- Moisture content was measured using ZR water nets (FD-600-2 Type, Kett Electric Laboratory, Japan).

- The Colorimeter used was from Juki Co., Ltd. (JP 7100 F, Japan).

- Instron: Instron, 4464 Model, USA

\section{3 . Processing procedure}

Raw materials were washed and cut horizontally into about 1 -cm-thick piecesand, soaked in $2 \%$ sodium chloride and then in syrup with $2 \%$ calcium chloride for 1 hour. The samples were frozen at $-20^{\circ} \mathrm{C}$ in a freezer overnight after 
syruping, and then fried in vacuum and de oiled by centrifugation $(3,000 \mathrm{rpm})$ for $5 \mathrm{~min}$. The processing procedure is shown in Fig.1.

\section{Experimental Method}

According to Box et al., the combination of the concentration of the soaking syrup, frying temperature and frying time constitutes a threelevel design for the study of 3 variables, by represented $X_{1}, X_{2}$ and, $X_{3}$. Each variable had three levels, $-1,0$, and +1 representing the standard values of the code number. Soaking in $30^{\circ}$ Brix syrup for 1 hour, and frying at $100^{\circ} \mathrm{C}$ for $45 \mathrm{~min}$ are regarded as the central point in the experimental design. The experimental values of each factor are decided by the results of the pretest. The distribution experiment is shown Table 1. The moisture content, oil content, color, texture and sensory evaluation parameters were measured for each sample. The results of the sensory evaluation were analyzed by Response Surface Regression (RS REG) using SAS (Statistic Analysis System). Soaking syrup concentration $\left(\mathrm{X}_{1}\right)$, frying temperature $\left(\mathrm{X}_{2}\right)$ and frying time $\left(\mathrm{X}_{3}\right)$ were used as variable factors obtained during operation. The optimum conditions are based on the overall acceptability by sensory evaluation.

\section{Qualitative Analysis of Products}

(1) Moisture content determination Five grams of sample was ground using an osterizer blender (USA), placed in a water meter at $105^{\circ} \mathrm{C}$ for 60

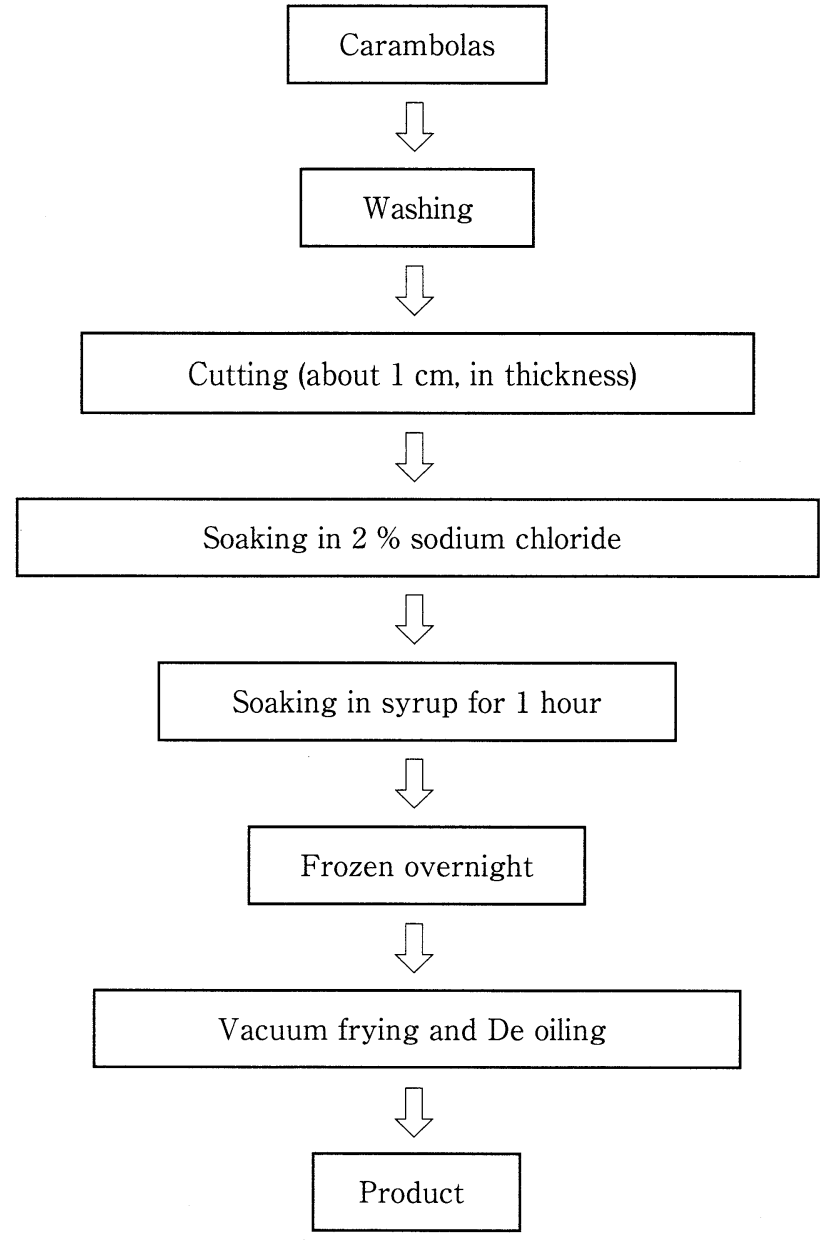

Fig. 1 Procedure of processing vacuum-fried carambolas

Table 1 Qualitative characteristics of vacuum-fried carambolas following different treatments

\begin{tabular}{cccccccc}
\hline $\begin{array}{c}\text { Treat- } \\
\text { ment }\end{array}$ & $\begin{array}{c}\text { Soaking } \\
\text { syrup } \\
\left({ }^{\circ} \text { Brix }\right)\end{array}$ & $\begin{array}{c}\text { Frying } \\
\text { temperature } \\
\left({ }^{\circ} \mathrm{C}\right)\end{array}$ & $\begin{array}{c}\text { Frying } \\
\text { time } \\
(\mathrm{min})\end{array}$ & $\begin{array}{c}\text { Moisture } \\
\text { content } \\
(\%)\end{array}$ & $\begin{array}{c}\text { Perforation } \\
(\mathrm{kg})\end{array}$ & $\begin{array}{c}\text { Oil } \\
\text { content } \\
(\%)\end{array}$ & $\begin{array}{c}\text { Color } \\
\text { (Whiteness) }\end{array}$ \\
\hline 1 & 40 & 110 & 45 & 11.73 & 0.4003 & 29.468 & 33.73 \\
2 & 20 & 110 & 45 & 15.47 & 0.5023 & 28.274 & 34.47 \\
3 & 40 & 90 & 45 & 24.63 & 0.8776 & 23.486 & 49.73 \\
4 & 20 & 90 & 45 & 29.5 & 0.9390 & 22.069 & 49.37 \\
5 & 40 & 100 & 50 & 17.57 & 0.5233 & 28.124 & 40.10 \\
6 & 20 & 100 & 50 & 19.43 & 0.5930 & 27.919 & 41.39 \\
7 & 40 & 100 & 40 & 21.53 & 0.6723 & 25.781 & 44.30 \\
8 & 20 & 100 & 40 & 24.76 & 0.7030 & 25.118 & 43.49 \\
9 & 30 & 110 & 50 & 10.73 & 0.3997 & 30.590 & 30.10 \\
10 & 30 & 110 & 40 & 15.66 & 0.4860 & 27.878 & 37.86 \\
11 & 30 & 90 & 50 & 23.6 & 0.7880 & 25.563 & 46.72 \\
12 & 30 & 90 & 40 & 26.9 & 0.9456 & 21.462 & 50.61 \\
13 & 30 & 100 & 45 & 20.3 & 0.6140 & 26.947 & 41.71 \\
15 & 30 & 100 & 45 & 20.98 & 0.6027 & 26.491 & 42.29 \\
\hline
\end{tabular}


minutes, and then read of its moisture content.

( 2 ) Oil content determination A Soxhlet-type extractor was used to extract oil with ether.

( 3 ) Color measurement The color of each sample was determined uding a color and color difference meter by determining the Hunter parameters "L", "a" and "b" were read. The meter was calibrated using a standard white plate $(\mathrm{X}=$ 93. 80, $Y=95.64, Z=113.70$ ) with

Hunter's whiteness $=100-\sqrt{(100-L)^{2}+\left(a^{2}+b^{2}\right)}$

(4) Texture analysis Instron was used in texture analysis. Probe model : 2830-005;2.95nm in diameter.

( 5 ) Sensory evaluation The sample was evaluated by 15 panelists using a 9 -score system. The score was evaluated by differential test, and sensory evaluation. Its overall performance was determined. Color, greasiness, flavor, and crispiness were used as individual sensory evaluation parameters. The overall performance was based on the evaluation Vacuum-fried carambolas by the panelists, the mine-score system was as follows: 1 , was dislike very much.5, acceptable; and 9 , like very much.

\section{Statistical Analysis and Determination Search of Optimum Conditions}

SAS statistical analysis was used to execute the variable analysis of the results of the sensory evaluation of each sample, and the significance of difference between the samples was determined using Duncan's Multiple Range Test (DMRT).

The overall acceptability of sensory evaluation was analyzed using the RSEZG equation in SAS. A multiple equation was drawn to describe the response surface figure. A homogeneity curve plotted using Excel and the optimum conditions were analyzed using the Figure Reconfirmation Test.

The triple sensory evaluation was carried out with the optimum combined conditions, the value evaluated using the equation under the optimum combined conditions was compared with the sensory value. The equation was considered feasible when there was no significant difference between these values.

\section{Result and Discussion}

The quality characteristics of vacuum-fried carambolas were determined. A three-variable and three-level fractional-factor design was decided through a pretest. Moisture content, perforation force, oil content, color, sensory characteristics were measured to determine the quality of the product. The quality characteristics of the product are shown as follows:

\section{Moisture content}

As shown in Table 1 , the lowest moisture content $(10.73 \%)$ was obtained in the $9^{\text {th }}$ test; at this moisture content, the frying temperature the frying time were $110^{\circ} \mathrm{C}$ and 50 minutes respectively. Thus, the higher the frying temperature and the longer the frying time, the lower the moisture content is. The moisture content was $15.66 \%$ during frying at $110^{\circ} \mathrm{C}$ for 40 minutes. At a fixed temperature, when the frying time was increased to 45 minutes, the moisture content decreased to $11.73 \%$; it decreased to $10.73 \%$ when the frying time was increased to 45 minutes. This phenomenon is similar to the falling rate drying period. The rate of dehydration decreased because moisture diffused from the inside to the outside. Another reason is that the high temperature induces the surface of the carambolas to form a hard film; this film prevents the diffusion of water from the inside.

\section{Perforation force}

In the test on perforation force, all the samples were perforated using the same probe, and the perforation speed $(150 \mathrm{~mm} / \mathrm{min})$ was the same. The perforated pressure was high for the probe diameter used and the surface was small. The following equation was used.

$$
\mathrm{P}=\mathrm{F} / \mathrm{A}
$$

Perforation force was shown as a measure of crispiness. The lower the perforation force, the better the crispiness was. The sample fried at $110^{\circ} \mathrm{C}$ for 50 minutes showed the lowest perforation force. This indicates that this sample was the best in crispiness; in contrast, the sample fried at $90^{\circ} \mathrm{C}$ for 40 minutes showed the highest perforation force, maybe because the frying temperature was low and the frying time is short, so that most of the moisture was retained in the sample. The perforation force was larger for a softer texture and the probe was hard to perforate. In general, the lower the moisture content, the better, the crispiness was.

\section{Oil content}

In table 1 , the oil content of vacuum-fried carambolas increased with frying temperature and frying time.

The increases in frying temperature and frying time induced the surface of the carambolas to rapidly form a gradient diffusion. The interval 
moisture turned to steam and evaporated from the surface by diffusion, and oil easily to penetrated the hydrophobic interval space of the carambolas. Thus, the lower the moisture content, the higher the oil content of the carambolas is.

\section{Color}

The higher the frying temperature and the longer the frying time, the darker the color, or the lower the whiteness is, as shown in Table 1. The whiteness was 50.61 when the product was fried at 90 ( $\mathrm{C}$ for 40 minutes, while it decreased to 30.10 when the product was fried at 110 ( $\mathrm{C}$ for 50 minutes; the difference was significant. The product showed a dark color when the frying temperature was more than 110 ( $\mathrm{C}$ and the frying time was longer than 50 minutes. Thus, the optimum conditions for frying carambolas were a frying temperature of less than 110 ( $\mathrm{C}$ and a frying time of less than 50 minutes.

\section{Sensory Evaluation}

Color, greasiness, flavor, crispiness and overall acceptability were used as sensory evaluation parameters. The higher the frying temperature and the longer the frying time, the darker the color, the higher the greasiness and the better the flavor of the product were. There was a higher evaluation on crispiness and overall acceptability when the product was fried at 100 (C for 45 minutes. There was a good relationship of crispiness with the overall acceptability. Thus, in judging the overall acceptability of vacuum-fried carambolas, crispiness was seen to be the most important factor.

\section{Optimum Conditions for Vacuum Frying Carambolas}

The analysis of the optimum conditions for vacuum frying carambolas was based on the data of the overall acceptability obtained by sensory evaluation, because the overall acceptability could be regarded as a measure of the preference of consumers.

The data of the overall acceptability was treated by SAS is using data regression. The regression coefficient of the overall acceptability shown in Table 3. The data could be shown in with layers of equation in three variables as follows:

Table 3 Regression coefficients and overall acceptabilities

Regression Overall acceptability

\begin{tabular}{ll}
\hline $\mathrm{A}_{0}$ & 6.680 \\
$\mathrm{~A}_{1}$ & 0.406 \\
$\mathrm{~A}_{2}$ & 0.625 \\
$\mathrm{~A}_{3}$ & 0.454 \\
$\mathrm{~A}_{12}$ & 0.283 \\
$\mathrm{~A}_{13}$ & -0.120 \\
$\mathrm{~A}_{23}$ & -0.458 \\
$\mathrm{~A}_{11}$ & -1.430 \\
$\mathrm{~A}_{22}$ & -0.868 \\
$\mathrm{~A}_{33}$ & -0.635 \\
\hline
\end{tabular}

Table 2 Sensory evaluation values of vacuum-fried carambolas following different treatments

\begin{tabular}{ccccccccc}
\hline $\begin{array}{c}\text { Treat- } \\
\text { ment }\end{array}$ & $\begin{array}{c}\text { Soaking } \\
\text { syrup } \\
\left({ }^{\circ} \text { Brix }\right)\end{array}$ & $\begin{array}{c}\text { Frying } \\
\text { temperature } \\
\left({ }^{\circ} \mathrm{C}\right)\end{array}$ & $\begin{array}{c}\text { Frying } \\
\text { time } \\
(\mathrm{min})\end{array}$ & $\begin{array}{c}\text { Color } \\
\text { Greasiness }\end{array}$ & $\begin{array}{c}\text { Flavor } \\
\text { ness }\end{array}$ & $\begin{array}{c}\text { Crispi- } \\
\text { acceptability }\end{array}$ \\
\hline 1 & 40 & 110 & 45 & $8.00 \mathrm{ab}$ & $5.33 \mathrm{c}$ & $6.87 \mathrm{a}$ & $6.47 \mathrm{~b}$ & $5.59 \mathrm{c}$ \\
2 & 20 & 110 & 45 & $7.73 \mathrm{~b}$ & $6.33 \mathrm{~b}$ & $6.87 \mathrm{a}$ & $5.60 \mathrm{c}$ & $4.58 \mathrm{e}$ \\
3 & 40 & 90 & 45 & $3.93 \mathrm{f}$ & $3.33 \mathrm{f}$ & $5.20 \mathrm{~b}$ & $3.47 \mathrm{e}$ & $3.62 \mathrm{fg}$ \\
4 & 20 & 90 & 45 & $3.67 \mathrm{f}$ & $3.33 \mathrm{f}$ & $4.13 \mathrm{c}$ & $3.20 \mathrm{e}$ & $3.74 \mathrm{f}$ \\
5 & 40 & 100 & 50 & $6.87 \mathrm{c}$ & $5.20 \mathrm{c}$ & $5.20 \mathrm{~b}$ & $6.53 \mathrm{~b}$ & $5.60 \mathrm{c}$ \\
6 & 20 & 100 & 50 & $6.87 \mathrm{c}$ & $4.33 \mathrm{de}$ & $5.20 \mathrm{~b}$ & $6.53 \mathrm{~b}$ & $4.66 \mathrm{e}$ \\
7 & 40 & 100 & 40 & $4.53 \mathrm{e}$ & $3.27 \mathrm{f}$ & $4.20 \mathrm{c}$ & $4.53 \mathrm{~d}$ & $4.81 \mathrm{e}$ \\
8 & 20 & 100 & 40 & $4.60 \mathrm{e}$ & $3.27 \mathrm{f}$ & $4.00 \mathrm{c}$ & $4.27 \mathrm{~d}$ & $3.39 \mathrm{~g}$ \\
9 & 30 & 110 & 50 & $8.40 \mathrm{a}$ & $7.33 \mathrm{a}$ & $3.00 \mathrm{~b}$ & $5.53 \mathrm{c}$ & $5.66 \mathrm{c}$ \\
10 & 30 & 110 & 40 & $6.53 \mathrm{c}$ & $6.33 \mathrm{~b}$ & $5.80 \mathrm{~b}$ & $4.53 \mathrm{~d}$ & $5.79 \mathrm{c}$ \\
11 & 30 & 90 & 50 & $4.80 \mathrm{e}$ & $4.27 \mathrm{de}$ & $3.00 \mathrm{~d}$ & $2.60 \mathrm{f}$ & $5.48 \mathrm{~d}$ \\
12 & 30 & 90 & 40 & $2.67 \mathrm{~g}$ & $2.27 \mathrm{~g}$ & $3.27 \mathrm{~d}$ & $1.20 \mathrm{~g}$ & $3.78 \mathrm{f}$ \\
13 & 30 & 100 & 45 & $5.40 \mathrm{~d}$ & $4.67 \mathrm{~d}$ & 5.27 & $6.53 \mathrm{~b}$ & $6.55 \mathrm{ab}$ \\
14 & 30 & 100 & 45 & $5.53 \mathrm{~d}$ & $4.13 \mathrm{e}$ & $5.47 \mathrm{~b}$ & $6.80 \mathrm{~b}$ & $6.90 \mathrm{a}$ \\
15 & 30 & 100 & 45 & $5.53 \mathrm{~d}$ & $5.60 \mathrm{c}$ & $5.47 \mathrm{~b}$ & $7.47 \mathrm{a}$ & $6.59 \mathrm{ab}$ \\
\hline
\end{tabular}




\section{$\mathrm{Y}:$ Response type}

$\mathrm{X}_{\mathrm{i}}$ : variable

The results of the variable analysis are shown in Table 4. The model, lack of fit and $\mathrm{R}^{2}$ were the most common indexes of results obtained by regression analysis.

(1) Model regression The model represented the fitness response to the model developed

(2) Lack of fit The lack of fit indicated the fit of the regression equation to the surface response.

(3) $R^{2} \quad R^{2}$ represented correlation of the prediction by determining the regression equation value to the real value. The nearer $\mathrm{R}^{2}$ is to $100 \%$, the better the result is.

From Table 4 , the regression of the model indicated a significant difference. This showed that the model was fit to study the response state response. The lack of fit was not significantly different, the regression equation is fit to the reality of the response surface, with a value of 97.69 ? Thus the regression model is fit to the fact. The response surface figure and the homogeneity curve could be drawn from the regression equation.

Table 4 Variable analysis of overall acceptabilities of vacuum-fried carambolas

\begin{tabular}{ccc}
\hline Source & df & $\begin{array}{c}\text { Sum of squares of } \\
\text { overall acceptability }\end{array}$ \\
\hline Model & 14 & $273.48^{(1)}$ \\
Linear & 3 & 6.092 \\
Quadratic & 3 & 10.510 \\
Cross product & 3 & 1.214 \\
Total regress & 9 & 17.816 \\
Lack-of-fit & 3 & $0.348^{(2)}$ \\
Pure error & 2 & 0.073 \\
Total error & 5 & 0.422 \\
\% Variability explained $\left(\mathrm{R}^{2}\right)$ & & 97.69 \\
\hline
\end{tabular}

(1) It was significant difference at $1 \%$ level.

(2) It was no significant difference at $5 \%$ level.

Table 5 Variable analysis of integral of total function from sum of overall acceptability of variance

\begin{tabular}{lcc}
\hline \multicolumn{1}{c}{ Process variable } & df & $\begin{array}{c}\text { Sum of overall } \\
\text { acceptability }\end{array}$ \\
\hline Syrup concentration (X 1) & 4 & $9.248^{(1)}$ \\
Frying temperature (X 2) & 4 & $7.060^{(1)}$ \\
Frying time (X 3) & 4 & $4.031^{(2)}$ \\
\hline
\end{tabular}

(1) Significantly different at $1 \%$ level.

(2) Not significant different at $5 \%$ level.
The integrated total function of overall acceptability from the triple variance of the procedure is shown in Table 5 . There were significant differences in the integrated total function of syrup concentration, frying temperature and frying time. These factors were the temperate variance on the product.

In general, frying temperature and frying time are the control points parameters of vacuum-fried products, to improve product quality. Syrup concentration was also used as variance. $-1,0$, and 1 were used to represent the step codes of syrup concentration. These codes were introduced to the regression multi equation. the equation describing the response character is expressed as follows.

$$
\begin{aligned}
\text { For } \times & 1=-1, \\
\mathrm{Y}= & 4.88+0.342 \times 2+0.574 \times 3-0.458 \times 2 \times 3 \\
& -0.868 \times 2^{2}-0.635 \times 3^{2} \\
\text { For } \times & 1=0, \\
\mathrm{Y}= & 6.680+0.625 \times 2+0.454 \times 3-0.458 \times 2 \times \\
& 3-0.868 \times 2^{2}-0.635 \times 3^{2} \\
\text { For } \times & 1=-1, \\
\mathrm{Y}= & 5.656+0.908 \times 2+0.334 \times 3-0.458 \times 2 \times \\
& 3-0.868 \times 2^{2}-0.635 \times 3^{2}
\end{aligned}
$$

The response surface figure and homogeneity curve could be drawn from the above three regressions as Fig.2 A.

From the response figure, the sample soaked in $30^{\circ}$ Brix has a higher overall acceptability; this shows that consumers would like the product soaked in $30^{\circ}$ Brix syrup concentration, and fried at $103^{\circ} \mathrm{C}, 46$ minutes, it was found that frying at $104^{\circ} \mathrm{C}$ for 41 minutes showed the higher overall acceptability. This result might gave led to the variation of the panel test. Thus, the optimum conditions for vacuum frying carambolas were a $30^{\circ}$ Brix syrup concentration, a $108^{\circ} \mathrm{C}$ frying temperature and a $46 \mathrm{~min}$ in frying time.

\section{Reconfirmation}

A reconfirmation test was carried out to support the panel test of the product prepared under optimum conditions. The experimental overall acceptability is shown in Table 6 , the predicted values obtained using the equation of the step code transferred under the optimum conditions are also shown in Table 6. There was no significant difference between the experimental and predicted values, so the experimental equation and optimum 

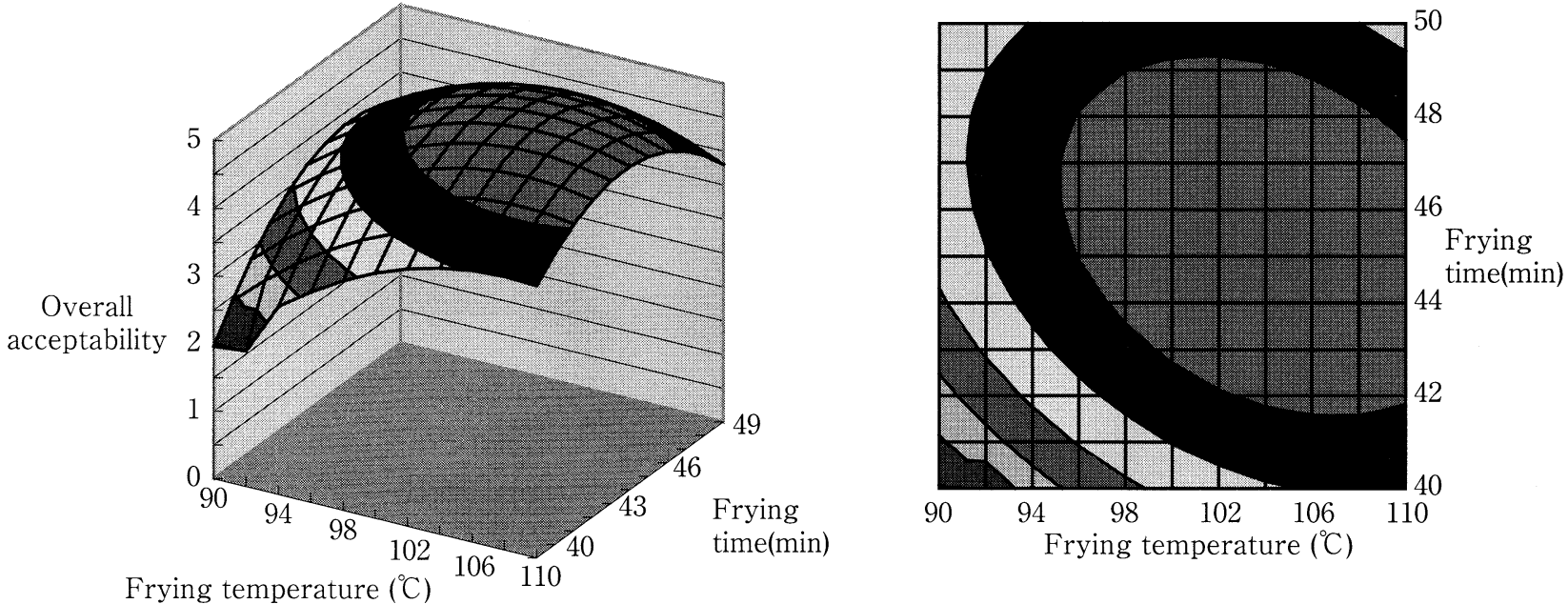

Fig. $2 \mathrm{~A}$ Overall acceptability of response surface and homogeneity curve at $20^{\circ}$ Brix $\left(\mathrm{x}_{1}=-1\right)$ syrup concentration
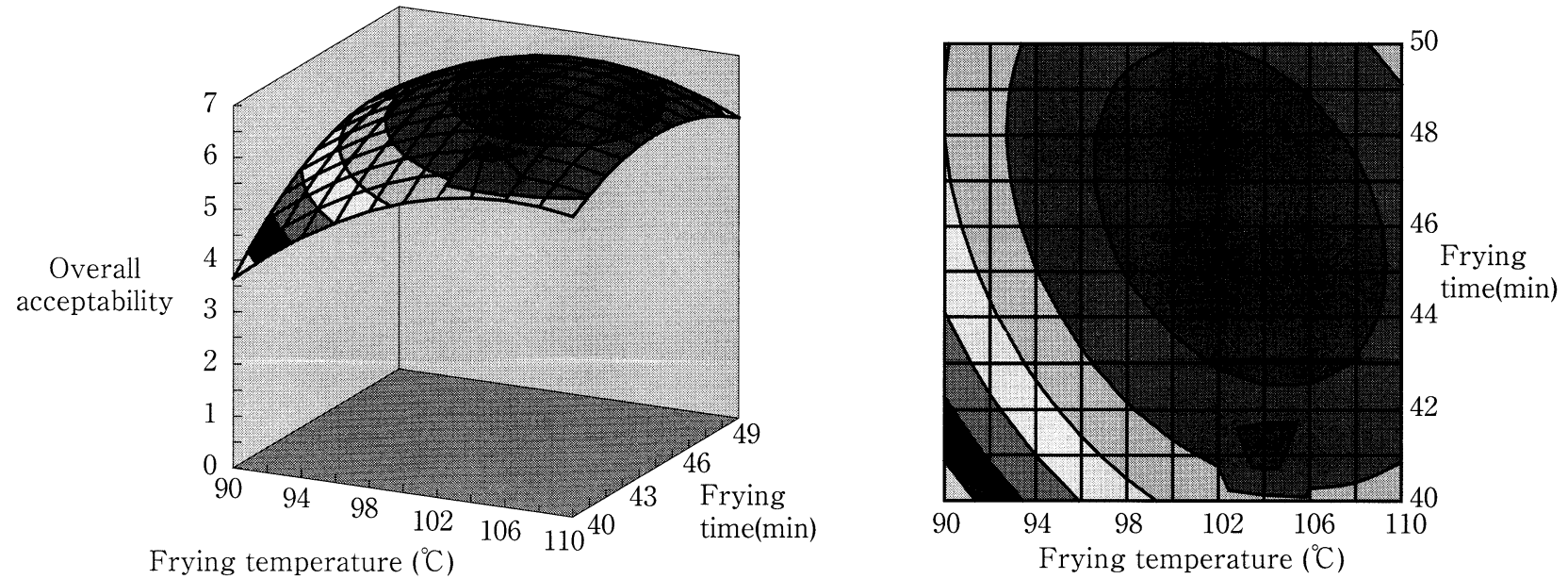

Fig. 2 B Overall acceptability of response surface and homogeneity curve at $30^{\circ}$ Brix $\quad\left(\mathrm{x}_{1}=0\right)$ syrup concentration
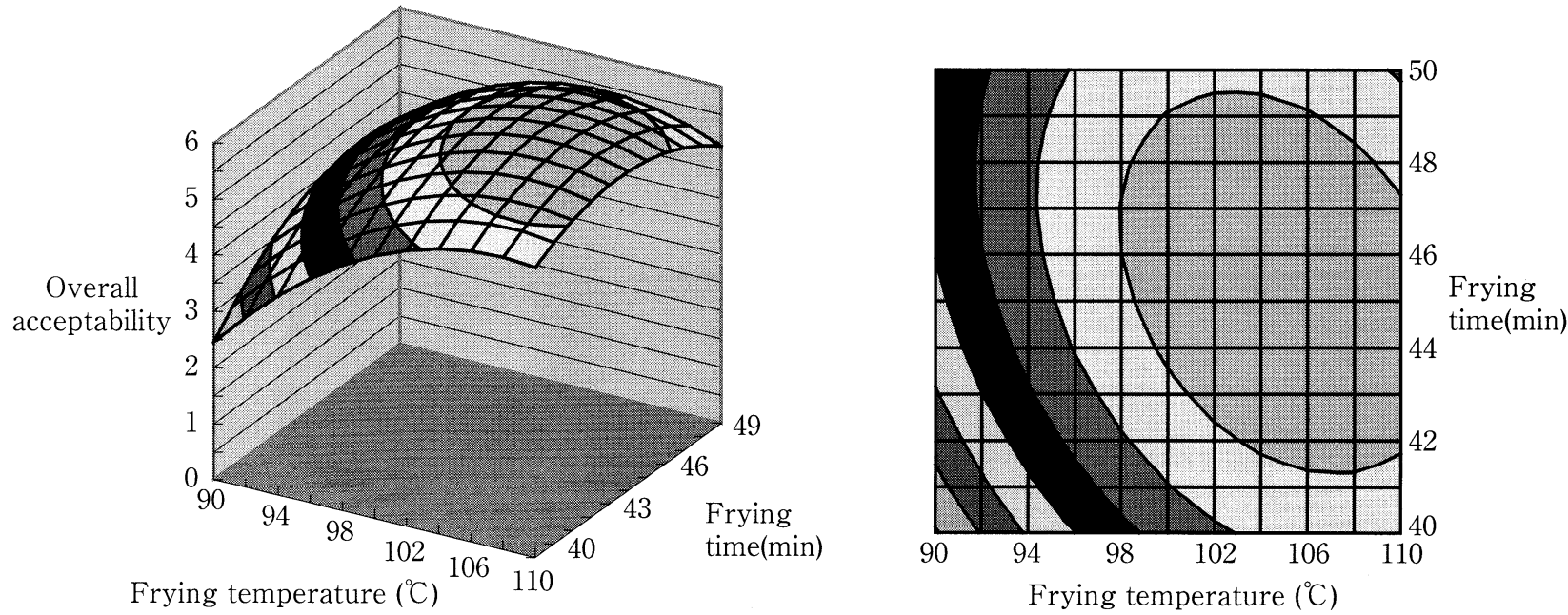

Fig. 2 C Overall acceptability of response surface and homogeneity curve at $40^{\circ}$ Brix $\left(\mathrm{x}_{1}=1\right)$ syrup concentration 
Table 6 Comparison of predicted value and experimental value

\begin{tabular}{lccc}
\hline & $\begin{array}{c}\text { Experimental } \\
\text { value }\end{array}$ & $\begin{array}{c}\text { Predicted } \\
\text { value }\end{array}$ & $\begin{array}{c}\text { Difference } \\
(\%)\end{array}$ \\
\hline $\begin{array}{l}\text { Overall } \\
\text { acceptability }\end{array}$ & 7.78 & 7.84 & 0.771 \\
\hline
\end{tabular}

conditions could be fit to improving the procedure of vacuum frying.

\section{Conclusions}

The optimum conditions for the vacuum frying carambolas was achieved by the response surface method, and the conditions were also reconfirmed by a test : $30^{\circ}$ Brix syrup concentration, $103^{\circ} \mathrm{C}$ frying temperature and $46 \mathrm{~min}$ frying time. There was no significant difference between consumer acceptability and the predicted value. Moisture content was the most important factor affecting the quality of vacuum-fried carambolas.

There was large difference between fresh carambolas and vacuum-fried carambolas in terms of appearance, texture, flavor, and commercial aspects as a snack food. The quality vacuum-fried carambolas was affected by the conditions of pretreatment and processing. Thus, it was difficult to make good-quality vacuum-fried carambolas. RSM was used in this experiment to determine the optimum conditions for processing vacuum-fried carambolas successfully. Other new product developments were obtained under the optimum conditions also by RSM.

\section{References}

1) Box, G. E. P. and Behnken, D. W.: Some new three level designs for the study of quantitative variables, Technometrics, 2 (4), 455 475 (1960)

2 ) Box, G. E. P., Hunter, W. C. and Hunter, J. S. Statistics for experimenters (John Wiley and Sons, New York), pp. 510 539 (1978)

3 ) Choudhury, I. A. and Baradie, E. I. : Machinability assessment of inconel 718 by factorial design of experiment coupled with response surface methodology, Journal of Materials Processing Technology, 95 (1-3), 30 39 (1999)

4 ) Fleischmann, P., Watanabe, N. and WinTERHALTER, P.: Enzymatic carotenoid cleavage in star fruit, Averrhoa carambola, Phytochemistry, 63 ( 2), 131 137 (2003)
5 ) Garayo, J. and Moreira, R.: Vacuum frying of potato chips, Journal of Food Engineering, 55 (2), 181 191 (2002)

6 ) Kuan, C. C.: The study on the drying of lemons, Master of food science of national pingtung Unverisity of science and technology (2002)

7) Wu, M. C., Lu, W. S. and Kuo, H.T.: Effects of oil-blanching time, Vacuum Frying Temperature and time on the quality of fried taro sticks, Bulletion of National Pingtung University of Science and Technology, 7 ( 2), 103 113 (1998)

8) Roberto, N. E. and Crane, J. H.: Selective pruning and crop removal increase early-season fruit production of carambola (Averrhoa carambola L.), Scientia Horticulturae, 86 ( 2), 115 126 (2000)

9) Shyu, S. L. and Hwang, L. S.: Effects of processing conditions on the quality of vacuum fried apple chips, Food Research International, 34 $(2-3), 133 \sim 142$, (2001)

10) Vohra, A. and Satyanarayana, T.: Statistical optimization of the medium components by response surface methodology to enhance phytase production by Pichia anomala, Process Biochemistry, 37 ( 9), 999 1004, (2002)

11) Yusof, S. and LEE, K. C.: Effects of Brix, processing techniques and storage temperature on the quality of carambola fruit cordial, Food Chemistry, 59 ( 1), 27 32 (1997)

\section{ゴレイシをバキューム・フライにする 最適条件に関する研究 \\ 侯 智耀 ${ }^{* 1} \cdot$ 吳 柏志 ${ }^{* 1} \cdot$ 楊 鋼誠 ${ }^{* 1}$ \\ 黄 湘玲 ${ }^{* 1} \cdot$ 吳 明昌 ${ }^{* 1}$ \\ * 1 屏東科技大學食品科學系 \\ (下91201 台灣屏東縣内埔郷學府路 1 號)}

本研究ではゴレイシを，いくつかの条件の下でバキュ 一ム・フライにする際の, 製品品質に及ぼす影響を調べ た。3 段階式反応表面法の製造工程に打いて, シラップ に漬け込む時間や，バキューム・フライの温度や時間な どを変えた場合の, 品質への影響をパネル・テストを行 って調べた。評価がもっともよかったものは原料を $30^{\circ}$ Brixのシラップに漬け込んで 1 時間後に $108^{\circ} \mathrm{C} て ゙ 46$ 分間 バキューム・フライにしたものであった。モデル式で検 証してみると, 最適漬込み時間, 最適バキューム・フラ イ温度および時間の組み合わせで, もっともよい品質の 製品が得られ，それは110ネルテスト，一致した。

(平成17年 3 月 15 日受付，平成 17 年 8 月 22 日受理) 